\title{
Um romance emblemático de Júlia Lopes de Almeida: crise e queda de um sistema
}

\author{
An emblematic novel by Julia Lopes de Almeida: crisis and fall of a system
}

\author{
ZAHIDÉ LUPINACCI MUZART ${ }^{1}$ \\ Universidade Federal de Santa Catarina/CNPq - Florianópolis - Santa Catarina - Brasil
} a

\begin{abstract}
Resumo: Neste artigo, faço breve apresentação da escritora Júlia Lopes de Almeida e me detenho mais no romance $A$ falência, analisando as personagens mais importantes. Nessa perspectiva, procuro estabelecer as razões do adultério de Camila, a personagem principal.

Palavras-chave: Júlia Lopes de Almeida; Adultério; Suicídio

Abstract: In this article, I briefly introduce the writer Júlia Lopes de Almeida, focusing on the novel A falencia and on the analysis of the most important characters. I try to establish the reasons of the adultery of Camila, which is the main character.
\end{abstract}

Keywords: Júlia Lopes de Almeida; Adultery; Suicide

$\mathrm{Na}$ história do romance de mulheres, depois do momento inicial em que umas, as pioneiras, com suas pequenas narrativas, se esforçavam no caminho da literatura, ocorre o aparecimento de outras, resultantes de empenho das antecessoras. Muitas destas novas escritoras, por ingenuidade, inexperiência ou receio da crítica e da própria família, permaneciam na linha do romantismo, embora o movimento já estivesse ultrapassado. Outras, porém, já propendiam para o realismo e, até mesmo, para um naturalismo nada extremado - brando - que eu classifico de matizado, por força das cores róseas que ainda lhes tingiam as narrativas nem tão analíticas, nem muito exatas, em descompasso com as características destes movimentos literários.

Essas escritoras são numerosas. Cito, portanto, somente algumas: Carmen Dolores (1852-1910), Maria Benedita Bormann (1853-1893), Inês Sabino (1853-1911), Francisca Clotilde (1862-1932), Amélia Beviláqua (18631946) e, naturalmente, Júlia Lopes de Almeida (18621934). Este momento de extraordinário florescimento da

\footnotetext{
Zahidé Lupinacci Muzart. Professora titular (aposentada) da Universidade Federal de Santa Catarina (UFSC), continua atuando no curso de Pós-Graduação em Literatura dessa Universidade. É pesquisadora 1-A do CNPq. Organizou, entre outros, os livros Escritoras brasileiras do século XIX, volumes I, II e III; Mariana Coelho: a evolução do feminismo.(Imprensa Oficial do Gov. do Paraná, 2002). Com o objetivo de recuperar parte da produção da mulher brasileira no século XIX, em 1996, fundou em Florianópolis a Editora Mulheres, juntamente com Susana Bornéo Funck.

2 Cf. MUZART, Zahidé Lupinacci et. al. Escritoras brasileiras do século $X I X$. Florianópolis: Mulheres; Santa Cruz do Sul: EDUNISC, 3v.
}

literatura feminina entre nós é o das mulheres nascidas no século XIX, mas cujas publicações, em grande parte, ultrapassam o final do século XIX e se situam no século XX. ${ }^{2}$

No século XIX, século da literatura no mundo, com a literatura exercendo como nunca sua função social, os escritores eram bastante respeitados, as conferências literárias, um acontecimento social. A vivência da literatura - privilégio das classes mais altas - constituía importante vertente de lazer e cultura da qual as mulheres não estavam excluídas, como leitoras, como ouvintes, como assistentes, nos salões e teatros. Mas o outro lado, o de quem produz literatura, que já beirava o profissionalismo, deste, a mulher esteve excluída por preconceito, pela religião, pelos limites do papel que deveria desempenhar na sociedade burguesa. Apesar desses impedimentos, no entanto, sabemos que a Inglaterra, por exemplo, deve à mulher o nascimento do romance, no século XVIII. Até hoje, lemos com muito gosto os romances de Jane Austen, de Elizabeth Gaskell, de George Eliot, bem superiores aos romances franceses da mesma época. No Brasil, esse percurso para as mulheres foi mais difícil, como é natural. A literatura serviu de válvula de escape do confinamento em que viviam. Algumas tiveram consciência da literatura como profissão, tal como Nísia Floresta, que escreveu romances, diários, cartas, poemas sempre com objetivo de publicação; ou como Maria Benedita Bormann, que tematizou a mulher escritora, a mulher artista no romance 
Lésbia, e, ainda, no mesmo rastro, Inês Sabino, que mostrou alta consciência de suas possibilidades literárias e da importância de preservar os nomes das outras escritoras em Mulheres illustres do Brazil. Foram poucas, porém, as que puderam buscar essa realização profissional, que puderam vencer os preconceitos do meio, da família. Elas não tinham acesso às boas escolas, as suas leituras eram orientadas para o ideal mulher "do lar", não tinham liberdade de movimentos, de viagens. E, sobretudo, não tinham a liberdade de discutir suas ideias. Eu penso que não é somente por causa dos homens, mas e muito por causa das próprias escritoras, das próprias mulheres que não tinham o devido respeito por suas atividades, as quais nunca foram consideradas por elas mesmas como importantes, como essenciais em suas vidas.

Antes de qualquer atividade ligada à literatura, ao fazer literário, vinha a atividade doméstica, vinha o cuidado com a casa, o marido, os filhos. Isso está em muitos textos, está em Julia Lopes de Almeida, por exemplo, nos dois livros que publicou: Conselhos às noivas, 1905, e o Livro das donas e donzelas...; está em Maria Amalia Vaz de Carvalho, Mulheres e crianças, de 1887; está em Aimé Martin e outros livros dedicados exclusivamente à leitura das mulheres. Ao lado da crítica das próprias mulheres, tivemos o cerceamento da Igreja Católica, que exerceu um papel importante no comportamento feminino. Um exemplo, o livro de Frei Pedro Sinzig, Através dos romances (em que estabelece notas sobre 21553 livros de 6657 autores). ${ }^{3}$ Neste, os próprios romances de Júlia Lopes de Almeida são violentamente censurados, como A Silveirinha. O medo da família, o medo dos maridos, o medo da comunidade em que viviam cortava-lhes as asas e impelia-as a, literariamente, repetir o estabelecido e bem aceito.

É esse cerceamento, essa autocensura das próprias escritoras que se reflete no uso de pseudônimos e, em sua produção literária, nos permite analisar o resultado. As escritoras nascidas no século XIX não privilegiaram o novo e, quando o fizeram, já foi com ar de anacronismo, como no caso de Albertina Bertha, que publica suas narrativas ligadas ao simbolismo, quando o modernismo já progredia entre nós; e outras poetisas que continuaram a privilegiar o Romantismo no final do século. Além dessa observação, cumpre-nos acentuar a quase ausência da mulher em uma ficção que privilegie o simbólico, dando preferência para temas do cotidiano, para retratar a vida das mulheres de sua época e as condições por elas encontradas. E fica a pergunta das razões da ausência das escritoras em certos gêneros, certos temas. Já o tinha observado quanto à ausência da mulher na poesia simbolista, há tempos atrás. A mulher, com os pés bem fincados no chão, na terra, na realidade, permitiu-se sonhar até certo ponto e romanticamente. As elucubrações de um tipo de literatura mais escapista e mais sensorial, ou de um naturalismo mais preso à escola, ficam-lhe estranhas e distantes.

Entre as raras vencedoras, salienta-se, então, e com grande consciência de exercer a literatura como profissão, de viver da literatura, Júlia Lopes de Almeida. Casada com um homem com ideias mais largas, oriunda de um lar moderno, com um pai que a estimulou a escrever, essas são algumas das razões que a levaram a ser quem foi. Em seu acervo, há cadernetinhas com anotações de vendas dos livros, dos preços, do recebido. ${ }^{4}$ Isso bem mostra sua organização e de como encarava sua atividade com seriedade, pensando-a não como um bibelot decorativo, mas como missão. É ela, seguramente, a escritora brasileira mais importante deste período a quem a feminista portuguesa, sua coetânea, Guiomar Torresão, considerou "a primeira escritora do seu país", em elogioso artigo, postumamente publicado em A Mensageira, cuja capa ostentava foto de Júlia Lopes. ${ }^{5}$ Mais recente, porém, foi considerada consoante a opinião de Peggy Sharpe $-{ }^{6}{ }^{6}$ como a "primeira dama" da literatura brasileira da belle-époque.

Sempre me perguntei das razões para o esquecimento de Júlia Lopes de Almeida, autora de uma obra consistente em número e em qualidade. Numa fase de autores bastante medíocres, foi ela um dos melhores escritores brasileiros da nossa belle-époque tupiniquim.

Muito louvada em sua época, ela foi sendo paulatinamente esquecida já na década inicial do modernismo e nos anos 30 e 40, o que não deixa de ser muito estranho, dado que a literatura dessa época não apresenta traços tão diferenciados do estilo e da temática da autora. Lúcia Miguel-Pereira, uma das raras críticas a escrever sobre ela, não lhe faz justiça em História da literatura brasilei$r a$ - prosa de ficção. ${ }^{7}$ Mesmo assegurando-lhe a primazia entre escritoras mulheres, pois afirma que Júlia Lopes "é a maior figura entre as mulheres escritoras de sua época", 8 insiste em que isso não quer dizer muito, já que:

\footnotetext{
3 Frei Pedro Sinzig. Através dos romances. Guia para as consciências, Edição das Vozes de Petrópolis, 1923.

4 O acervo de Júlia Lopes de Almeida, cuidadosamente preservado por seu neto, Dr. Claudio Lopes de Almeida, foi por este doado à Academia Brasileira de Letras, onde também encontra todos os cuidados necessários.

5 Os comentários de Guiomar Torresão foram publicados em A Mensageira de 15 de junho de 1899. Ver A Mensageira. v. 2. Ed. fac-similar. São Paulo: Imprensa Oficial do Estado, Secretaria de Estado da Cultura, 1987, p. 101

6 Cf. SHARPE, Peggy. Júlia Lopes de Almeida. In: MUZART, Zahidé Lupinacci. Escritoras brasileiras do século XIX. v. 2. Florianópolis: Mulheres; Santa Cruz do Sul: EDUNISC, 2004, p. 188.

7 MIGUEL-PEREIRA, Lúcia. História da literatura brasileira - prosa de ficção. De 1870 a 1920. 3. ed. Rio de Janeiro: José Olympio; Brasília: INL, 1973, p. 269-271.

8 "Na verdade, é a maior figura entre as mulheres escritoras de sua época, não só pela extensão da obra, pela continuidade do esforço, pela longa vida literária de mais de quarenta anos, como pelo êxito que conseguiu, com os críticos e com o público; todos os seus livros foram elogiados e reeditados, vários traduzidos, sendo que se consumiu em três meses a primeira tiragem da Família Medeiros". Ibid.
} 
[...] a ficção não conta entre nós, no período aqui estudado, muitas mulheres. Apenas doze nomes revelou uma busca cuidadosa em dicionários bibliográficos, obras críticas, velhos catálogos de livrarias, jornais e revistas, e, dessa dúzia, muito poucos chegaram até nós; esgotados os seus livros que não existem nem mesmo na Biblioteca Nacional, temos que aceitar como definitivo o juízo dos contemporâneos, tácito no silêncio que se fez em torno da maioria dessas escritoras, registradas tão-somente por Sacramento Blake. ${ }^{9}$

Baseando-se na crítica um tanto apressada de Nestor Vítor, Lúcia Miguel-Pereira conclui que

[...] os livros de Júlia Lopes, se nada possuem de original, revelam, no seu tom familiar, na sua completa ausência de artifícios, de afetação, inegáveis dons literários. A simplicidade, tão rara sempre e, ainda mais no tempo em que escreveu, é a sua qualidade dominante. ${ }^{10}$

Esta ainda é, nos anos 50, o melhor da crítica sobre nossa autora,pois sua obra, bastante comentada e louvada na época da publicação de seus grandes romances, foi desaparecendo aos poucos, sendo que o texto de Lúcia Miguel-Pereira se apresenta como uma voz bastante rara naqueles anos (o livro teve a primeira edição em 1950).

Júlia Lopes, nascida no Rio de Janeiro, mas filha de pais portugueses, também casada com um intelectual português, tendo passado largos anos em Portugal, cujas leituras seguramente se iniciaram com autores portugueses e que deveriam contemplar a obra de Eça de Queirós, trai, em sua escrita, o que os críticos chamaram de tom lusitanizante. Talvez tenha sido o que a diferenciaria dos escritores brasileiros da época: um estilo muito cuidado, obediência à norma gramatical, a preocupação de não empregar vocábulos do falar oral, coloquial, para caracterizar a chamada cor local, em suma, um português castiço. O que a distinguiria de escritores renomados, como Coelho Neto, não seria o tom lusitanizante, mas a simplicidade de sua escrita, a busca da clareza e até a cadência de sua prosa, estilo que fez com que Lúcia Miguel-Pereira a elogiasse, embora a tenha incluído entre os escritores que classifica como "sorriso da sociedade", qualificação de que discordamos inteiramente. ${ }^{11}$

Desde então, fala-se na simplicidade do estilo de Júlia Lopes de Almeida. Parece-me que tal qualificação lhe foi atribuída pela comparação com alguns escritores de sua época, tais como Coelho Neto, cuja maneira de escrever rebuscada, barroca, cansava sobremaneira aos leitores. ${ }^{12}$ Já o estilo de Júlia é, sim, de grande simplicidade, mas não nos enganemos; é uma simplicidade trabalhada, cuidadosa, não é algo espontâneo. Ao analisar-lhe o estilo em A falência, encontramos um texto fluente, que parece simples, mas esse qualificativo é o resultado de trabalho constante.

Sobre o tom lusitanizante, Wilson Martins assim comenta, elogiando-lhe o romance $A$ viúva Simões:

A viúva Simões é um excelente romance, de grande força dramática, escrito num estilo brilhante e enxuto, com perfeito desenvolvimento narrativo. [...] Esse livro compara-se ao melhor Eça, se não for melhor do que Eça; o paralelo é inevitável; já que a técnica, os princípios de escola e o estilo (claramente lusitanizante em Júlia Lopes de Almeida) aproximam um do outro os dois escritores. ${ }^{13}$

Já Medeiros e Albuquerque, em Páginas de crítica, publicado em 1920, ao mesmo tempo em que lhe elogia bastante um conto, "Era uma vez", critica com humor seu pendor para o português de Portugal:

No trabalho de D. Julia Lopes encontra-se uma pequena questão do eterno e irritante problema da orthographia, que é por demais característico, para não merecer reparo.

D. Julia Lopes escreve preguntar e preguntou.

Preguntar, é talvez etimológico e pronunciado à portugueza, com o e absolutamente mudo, pode estar certo em Portugal. No Brazil, onde quasi não ha a noção do e mudo, preguntar é lingua de negro Mina. Não ha ninguém, tendo pelo menos medíocre instrucção, que entre nós pronuncie desse modo.

Quem, no Brasil, escreve preguntar, porque assim se pronuncia em Portugal, deve também querer que os nossos poetas rimem mãi com bem e tenha com banha. A primeira dessas rimas está até no hymno nacional republicano portuguez e a segunda em Antero do Quental.

Estão lá muito acertadamente, porque é assim que se pronuncia em Portugal. [...]

E ahi fica o único reparo ao pequeno e gracioso conto da illustre escriptora, conto que, por todas as outras razões, só merece elogios. ${ }^{14}$

\footnotetext{
${ }^{9}$ Ibid.

${ }^{10}$ Ibid.

${ }^{11}$ Na página 246, da edição de 1998, Lúcia Miguel-Pereira observa: "[...] esses escritores viam a literatura não como arte perturbadora e inquisitória por excelência, mas como a manifestação do bem-estar social, numa época de paz, eles próprios em regra, contentes com sua sorte, pertencentes à classe dominante, escrevem para distrair-se e para distrair os leitores. Uma palavra os explica: diletantismo.".

${ }^{12}$ Lima Barreto criticou-o, com um certo humor corrosivo: "O senhor Coelho Neto é o sujeito mais nefasto que tem aparecido em nosso meio intelectual... Ninguém lhe peça um pensamento, um julgamento sobre a nossa vida urbana ou rural... Coelho Neto fossilizou-se na bodega do que ele chama estilo, música do período, imagens peregrinas e outras coisas que são o cortejo da arte de escrever, mas não o fim próprio da literatura" (Apud ARNONI PRADO, Antonio. Lima Barreto: o crítico e a crise. São Paulo: Martins Fontes, 1989, p. 40).

${ }^{13}$ MARTINS, Wilson: História da inteligência brasileira. São Paulo: Cultrix; Editora daUniversidade de São Paulo, 1977-1979 (7 volumes). V. 5 (1897-1914), p. 12.

${ }^{14}$ ALBUQUerQUe, José Joaquim de Campos da Costa Medeiros e. Paginas de crítica. Rio de Janeiro: Leite Ribeiro \& Maurillo, 1920, p. 96.
} 
Ainda, entre críticos mais atuais, encontram-se boas observações. Estas são de Celso Pedro Luft:

Romancista e contista, de grande facilidade de inventiva e expressão, e regular poder de análise, [Júlia Lopes de Almeida] retrata em suas obras a evolução material, social, intelectual e moral do Rio de Janeiro do seu tempo. Sob o ponto de vista estilístico procurou aliar a técnica zolaísta a uma constante preocupação de linguagem artística. ${ }^{15}$

Júlia Lopes de Almeida escolheu pintar a sociedade de sua época e o fez nos vários romances com agudeza e perspicácia. E não procurou pintá-la sem problemas, ao contrário. Mas a inclusão entre os escritores "sorriso da sociedade" 16 talvez lhe tenha valido por retratar, preferencialmente, a sociedade da alta burguesia carioca - que foi o meio a que pertenceu. Em raros textos, como Memórias de Marta, entra na caracterização da vida dos proletários. Sobre as vicissitudes dos negros recém-saídos da escravidão, retrata a infeliz e maltratada Sancha, em A falência, cujo recurso de libertação the apareceria unicamente como o suicídio. Também já retratara os males da escravidão no romance $A$ família Medeiros, sua primeira incursão no assunto. Escrito antes da Abolição, mas só publicado depois, deixou de ter um maior sucesso de público e de crítica. Segundo Guiomar Torresão, no artigo citado,

[e]sse livro, onde se estereotipa o período de transição do trabalhador escravo para o trabalhador livre, é não só o documento de um alto espírito, afirmandose na exteriorização de uma idéia e na forma de conduzi-la e reproduzi-la, mas também a vibração de uma alma, condoendo-se da miserável condição do escravo, espezinhado pela ferocidade da lei e pelo egoísmo humano, e clamando em nome da sagrada causa dos fracos e dos desprotegidos contra o inexorável despotismo dos fortes. Da pena de uma senhora, trazendo a autorizá-la o vigor do seu talento e a prestigiosa eloquência da sua sensibilidade, brotou então uma das mais irresistíveis propagandas a favor do abolicionismo, um dos mais violentos protestos, exarado na pintura dos horrores da escravidão, contra o mercado da carne humana e com ele a apoteose da regeneração pelo trabalho, cujos fructos, já sazonados, constituem ao presente a riqueza, a gloria e a prosperidade do opulento Estado de S. Paulo.

De tal sorte que, se a Família Medeiros encontrasse nas duas literaturas, brasileira e portuguesa, a mesma larga vulgarização européa que obteve, pelo idioma em que era escrito, o célebre romance Cabana do pai Thomaz, Julia Lopes seria já hoje uma benemérita da humanidade e o seu nome gravar-se-ia em lettras imorredouras para a homenagem da posteridade, na mesma evidencia gloriosa onde se fixou o nome da grande romancista inglesa. ${ }^{17}$
Publicado em 1901, A falência salienta-se dentre os vários romances publicados por Júlia Lopes de Almeida. Não foi como outros romances, primeiro publicado em folhetins. Parece ter sido pensado, trabalhado e revisto por vários anos, quinze, no dizer de Leonora de Luca, ${ }^{18}$ e o resultado foi um de seus melhores romances, quiçá o melhor, conservando "até nossos dias, o frescor do estilo e a perspicácia da observação de costumes da autora". ${ }^{19}$

$\mathrm{Na}$ biografia, ainda inédita, ${ }^{20}$ escrita por sua filha, a declamadora Margarida Lopes de Almeida, ${ }^{21}$ fica esclarecida a origem deste romance:

Ainda em solteira publicou um livro de contos 'Traços e Iluminuras' com capa original de Rafael Bordalo Pinheiro que conservamos como preciosidade. Num desses contos 'A Falência' haveria de desenvolver-se depois em romance que iria firmar definitivamente o prestígio da autora.

No exemplar (62 edição) de minha biblioteca colou minha mãe esta nota, escrita com sua letra despretensiosa e miúda:

"Escrevi este romance duas vezes. A primeira em solteira, e dessa primeira feitura figuram dois capítulos no meu livro de contos 'Traços e Iluminuras' escrito ainda com o meu nome de menina. Esse romance rasguei-o, sentindo que lhe faltava o que o seu assunto exigia e que só depois de mulher eu lhe poderia dar completamente: o conhecimento da vida. A idéia ficou cantando no meu espírito e só depois de muitos anos de casada e cinco vezes mãe, foi que o escrevi do primeiro ao último capítulo, definitivamente."

Este detalhe caracteriza a honestidade intelectual da romancista. ${ }^{22}$

${ }^{15}$ LUFT, Celso Pedro. Dicionário de Literatura Portuguesa e Brasileira. Porto Alegre: Globo, 1979, p. 11.

16 "O escritor funciona nesta belle-époque como um jogral da sociedade, destacando-se pelo pitoresco e, por vezes, pelo anedótico. Fruto desse ambiente cultural, Afrânio Peixoto chega a conceber a literatura como "o sorriso da sociedade". Não têm sido poucos os ataques que o escritor sofreu por essa controvertida comparação. Entretanto, devemos julgá-lo com imparcialidade, pois a frase encarna com propriedade todo o espírito de uma época, expressada tão sinteticamente." MOREIRA, Nadilza. Disponível em: <http://www.prodema.ufpb.br/revistaartemis/numero1/ arquivos/artigos/artigos_finais/artigo nadilza.htm>.

17 TORRESÃO, Guiomar. A Mensageira, n. 29,15 jun., 1899, p. 100.

${ }^{18}$ DE LUCA, Leonora. Júlia Lopes de Almeida e o feminismo no Brasil da virada do século. Relatório final de pesquisa de Iniciação Científica. IFCH/UNICAMP. 1995

19 TELLES, Norma. Apresentação. In: A falência. Florianópolis: Mulheres; Santa Cruz do Sul: EDUNISC,2003.

${ }^{20}$ Este texto me foi enviado pelo Dr. Cláudio Lopes de Almeida, neto da escritora e guardião do acervo que, somente em 2011, doa para a Academia Brasileira de Letras.

${ }^{21}$ Ainda em criança, nos anos 40-50, morando na cidade de Cruz Alta, RS, tive a grande oportunidade de vê-la e de ouvi-la e a impressão deste evento ficou-me indelevelmente marcada. Tivemos o privilégio de compartilhar um programa de Cultura Artística muito atuante, criado e dirigido pelo dr. Mário Moraes, e, realmente, foi a única cidade do interior do estado a receber tão honrosa visita.

22 "Biografia de D. Julia", inédito de Margarida Lopes de Almeida. Documento no acervo da autora de propriedade do dr. Cláudio Lopes de Almeida. 
O conto "A falência" é apenas um curto esboço do que a escritora viria a desenvolver mais tarde no romance. O conto já se inicia com a falência do negociante e a repercussão entre o público e os empregados da firma, concentrando-se nos sentimentos de um destes, que é quem vai retratar o ex-chefe com muito afeto e piedade. O conto termina com a despedida dos dois. Parece-me que este é um exemplo do sistema da escritora, de seu planejamento na feitura de um romance, trabalhando uma ideia até estar satisfeita com ela.

Júlia Lopes de Almeida obteve, em sua época, grande atenção de críticos e resenhistas. Destes, salientam-se os textos de dois dos maiores críticos da belle époque: Nestor Vítor e José Veríssimo. Este, habitualmente contido, elogia-a bastante:

Depois da morte de Taunay, de Machado de Assis e de Aluísio Azevedo, o romance no Brasil conta apenas dous autores de obra considerável e de nomeada nacional - D. Júlia Lopes de Almeida e o Dr. Coelho Neto. Sem desconhecer o grande engenho literário do Sr. Coelho Neto, eu, como romancista, lhe prefiro de muito D. Júlia Lopes. ${ }^{23}$

E critica com rigor a obra de Celho Neto, salientandolhe a artificialidade de fundo e de forma.

Um livro louvado por José Veríssimo ${ }^{24}$ e Wilson Martins, ${ }^{25}$ dois críticos sempre parcos em elogios, traz um enredo não usual entre os romances das escritoras mulheres, entrecruzando-se o adultério de Camila, a esposa, e a derrocada financeira de Francisco Teodoro, o rico empresário exportador de café. Enredo não usual porque o amor/paixão, tema que, em geral, domina os romances da época, fica em segundo plano. O que vai prevalecer é a pintura de caracteres como os da filha Rute, violinista; de Noca, a empregada devotada; o de Nina, a moça acolhida por caridade e, sobretudo, o de Camila, a esposa adúltera, e seu amante, o médico Dr. Gervásio, uma figura bem traçada, uma espécie de epicurista que influencia toda a família do empresário. Todas as personagens, principais ou coadjuvantes, apresentam caracteres bem desenhados, bem traçados como as tias velhas de Camila que manifestam a opinião da sociedade sobre Francisco Teodoro e sua família, como se compusessem uma espécie de coro grego.

O português retratado em A falência, vindo de Portugal "com uma mão na frente e outra atrás", enriquece por meio do trabalho árduo e honrado. É uma personagem com muitas qualidades, humano e generoso. Casa-se por necessidade de fundar uma família e, pensando na questão da herança, desejando deixar descendência, assim se expressa: "Para que lhe serviria o que juntara, se o não compartilhasse com uma esposa dedicada e meia dúzia de filhos que the herdassem virtudes e haveres?".
Mais tarde, com os filhos já grandes, milionário, cede não só às sugestões de outro industrial, corretor na verdade um larápio que o engana -, mas, sobretudo, à própria vaidade de desejar ser reconhecido como o primeiro industrial do Rio, e participa de grande especulação financeira, fazendo falência e suicidando-se a seguir. Há egoísmo inconteste neste ato extremo, uma vez que a vergonha, a miséria e a reconstrução da vida são tudo o que resta para os que lhe sobreviveram.

O grande tema do romance $A$ falência está expresso no título. Júlia Lopes de Almeida retrata uma época bem conturbada no Brasil do início do século XX, na economia e na política. A escritora viveu-a, observou-a e a traduziu em seu romance. A falência seria o sinônimo da crise da época. Este não é o último romance de Júlia Lopes de Almeida, mas é o mais bem estruturado, maduro e repensado, original pela temática e muito atual: lida exatamente com os percalços por que passamos hoje: especulação nada ética de uns poucos, donos do capital, que resulta em tragédia para muitos. O que impressiona é que de 1901 para cá, apenas sofisticamos a crise e postergamos soluções. Um século depois, nós globalizamos crises e quedas. Ganância e ambição de visibilidade social moveram o já milionário Francisco Teodoro.

Examinando o panorama literário do primeiro ano do nosso século, a mencionada belle époque, escrevia José Veríssimo:

Mais talvez do que nenhum outro aspecto da vida social, ressente-se a literária das condições do meio e do momento. Isto posto, não era de esperar que a nossa vida literária tivesse no ano de 1901 [...] mais vigor, mais intensidade, mais riqueza e brilho do que teve [...] Com exceção dos governantes, sempre em toda a parte, em todos os tempos, até nas vésperas e na iminência das revoluções e das catástrofes, otimistas, todos sabem e sentem as desgraçadíssimas condições, materiais e morais, do nosso país... É claro que em tal momento a literatura, a poesia, a alta cultura do espírito, os estudos liberais, as artes tanto da escrita como do desenho, não podem absolutamente florescer. Já é assombro que não desapareçam de todo, e que contra as circunstâncias do meio e do momento teimem em viver. ${ }^{26}$

${ }^{23}$ VERÍSSIMO, José. Letras e literatos. Rio de Janeiro: José Olympio, 1936, p. 15

24 Id. Estudos de literatura brasileira (5 Série). Reedição. Belo Horizonte: Itatiaia; São Paulo: EDUSP, 1977. V. 5a Série, Um Romance da Vida Fluminense, p. 79-84, que trata do recém-lançado romance $A$ falência.

${ }^{25}$ MARTINS, Wilson. História da inteligência brasileira. São Paulo: Cultrix; EDUSP, 1977-1979 (7 volumes). v. 5, p. 194-195. Copio um trecho: "excelente romance de inspiração eciana sobre a vida de um português enriquecido nos negócios, mas que vai à bancarrota no clima de especulação que ainda persistia logo depois do Encilhamento. Cruzase com essa linha da narrativa, ou nela se contém, a história do adultério da mulher com o médico da família".

26 VERISSIMO, José. Trecho de História Literária. Correio da Manhã, Rio de Janeiro, 20 abril 1947. $2^{\text {a }}$ seção, p. 1, apud MIGUEL-PEREIRA, Lúcia. Escritos da maturidade. Organização e pesquisa de Luciana Viegas. Rio de Janeiro: Graphia Editorial, 1994, p. 75. 
As consequências da Guerra do Paraguai foram um enorme endividamento e a desestabilização do Império brasileiro, assim como o aparecimento de "novas elites de jovens intelectuais, artistas, políticos e militares, a chamada 'geração de 70', comprometida com uma plataforma de modernização". ${ }^{27}$ Valho-me da competente explanação a respeito, do historiador Nicolau Sevcenko, mesmo que seja uma citação um pouco longa:

A ideia das novas elites era promover uma industrialização imediata e a modernização do país 'a todo custo'. Os resultados foram dois, um fluxo inédito de penetração de capitais ingleses e americanos no país e a mais escandalosa fraude especulativa de todos os tempos no mercado de ações, chamada singelamente de 'o Encilhamento', numa referência ao ponto de partida do qual os cavalos disparam no turfe. Era a entrada triunfal do Brasil na modernidade.

$\mathrm{O}$ efeito direto dessa falcatrua desenfreada foi arruinar os capitalistas mais proeminentes da praça, os quais constituíram a elite econômica da era monárquica, propiciando a ascensão de uma nova camada de arrivistas, enriquecidos no jogo especulativo e nas negociatas dos primeiros anos do novo regime. ${ }^{28}$

Com efeito, a fase era de desânimo nacional. Cessara a agitação das lutas políticas dos primeiros anos da república, que, repercutindo em todos os meios, haviam arrastado à ação prática tantos escritores, bastando lembrar o florianista Raul Pompeia e o anti-florianista Olavo Bilac; murchara a euforia do encilhamento, que comunicara ao Rio um brilho fugaz e fizera cada carioca se julgar um milionário em potencial. Depois de tanta febre, seria inevitável a prostração, ao entrar o país na era de pacificação política e recuperação financeira inaugurada pelos primeiros presidentes civis. A deflação, pelos cortes que impunha às despesas públicas, pelos aumentos de impostos que tornava necessários, representava para o povo um penoso sacrifício. E as dificuldades materiais acarrretavam, moralmente, a descrença no regime e no futuro da nação. ${ }^{29}$

Júlia Lopes consegue, pois, também fazer uma literatura interessada, no sentido dado por Antonio Candido, que assim explicou um dos pressupostos norteadores da organização de Formação da literatura brasileira:

Quero me referir à definição da nossa literatura como eminentemente interessada. Não quero dizer que seja 'social', nem que deseje tomar partido ideologicamente. Mas apenas que é toda voltada, no intuito dos escritores ou na opinião dos críticos, para a construção duma cultura válida no país. Quem escreve, contribui e se inscreve num processo histórico de elaboração nacional. [...]

A literatura do Brasil, como a dos outros países latino-americanos, é marcada por este compromisso com a vida nacional no seu conjunto, circunstância que inexiste nas literaturas dos países de velha cultura. ${ }^{30}$
A obra de Júlia Lopes obedece a um projeto estético, mas também nacional. Deseja ela retratar sua época, seu tempo e contribuir para, no sentido positivista, o progresso do país. Sua consciência da saúde do país, da salvação da natureza é muito forte e avançada para a época em que poucos se preocupavam com isso. Assim, faz palestras, viaja pelo país preconizando mudanças na formação das moças e na vida das mulheres casadas ${ }^{31} \mathrm{e}$, com um senso incomum de ecologia, incentiva a plantação de árvores e flores, escreve sobre jardinagem. ${ }^{32}$ Em Viagens no meu país, escandaliza-se com o número de árvores destruídas quotidianamente para alimentar as caldeiras das fábricas e manufaturas que visita em Porto Alegre. Ao mesmo tempo em que elogia o progresso dessa que denomina Manchester local, reclama da destruição das florestas:

Desde que cheguei ao Rio Grande do Sul tenho a impressão de andar viajando em pleno reino mineral, tão insignificante me parece, relativamente, a vegetação no harmónico conjunto das suas areias, das suas águas e das suas pedras. Causa-me por isso certa estranheza vêr tamanha abundância de lenha nas fábricas que visito.

De que matas terão vindo essas árvores esquartejadas, amputadas e lascadas, que esperam ao vento e ao sol a hora suprema da sua ultima transformação?

Pergunto e respondem-me que elas foram trazidas das regiões ubérrimas do Rio Grande interior, das margens baixas dos rios ou dos dorsos das serras umbrosas.

Eu que adoro o arvoredo e trago na minha bagagem um livro de que faço propaganda activa, porque o escrevi certa da necessidade cada vez mais imperiosa e urgente do plantio da árvore no Brasil, não posso deixar de lastimar quando a vejo mal estimada [...] Certamente que o Brasil é uma terra de florestas, mas de florestas dizimadas, quando entretanto a sua glória e a sua fortuna estão exactamente dependentes da árvore cultivada!

Essas matas serranas de onde provém tanta madeira, serão ao menos replantadas?

A esta pergunta ninguém responde de modo claro e positivo. Quer isso dizer que não são replantadas; que não ha lei que obrigue o lenhador a substituir a

${ }^{27}$ SEVCENKO, Nicolau. Introdução. História da vida privada no Brasil. República: da Belle Époque à Era do Rádio. São Paulo: Companhia das Letras, 1998, p. 14

${ }^{28}$ Ibid, p. 15.

${ }^{29}$ MIGUEL-PEREIRA, Lúcia. Escritos da maturidade. Organização e pesquisa de Luciana Viegas. Rio de Janeiro: Graphia Editorial, 1994, p. 75.

${ }^{30}$ CANDIDO, Antonio. Prefácio da $2^{\mathrm{a}}$ edição. Formação da literatura brasileira (Momentos decisivos). v. 1. São Paulo: EDUSP; Belo Horizonte: Itatiaia, 1975, p. 18.

${ }^{31}$ Cf. Livro das noivas. 2. ed. Rio de Janeiro: Francisco Alves, 1905; e Livro das donas e donzelas. Rio de Janeiro: Francisco Alves, 1906.

${ }^{32}$ Cf. A árvore (coletânea de crônicas e poemas). Escrita em colaboração com o filho, Afonso Lopes de Almeida. 1. ed. Rio de Janeiro: Livraria Francisco Alves, 1916; Jardim florido. Jardinagem. 1. ed. Rio de Janeiro: Leite Ribeiro, 1922. 
árvore adulta que ele abate por outra árvore pequenina da mesma ou de melhor espécie, que perpetue na pátria o melhor tesouro da sua natureza e da sua previdência. Assim as lindas regiões montanhosas ou as margens férteis dos rios necessitados de sombra, de onde vem a lenha para os ventres insaciáveis dos fornos industriais se converterão pouco a pouco em sítios escalvados, sem poesia nem utilidade. ${ }^{33}$

Palavras sábias e proféticas de Júlia Lopes de Almeida! Este seu lado tem sido muito pouco acentuado pela crítica e os livros que escreveu a respeito não tiveram reedição. Segundo a filha Margarida, em entrevista para Noemi Flores,

Minha mãe estava sempre escrevendo um livro. Tinha o hábito de escrever diariamente, o que explica sua grande produção. Metodicamente, ela se dirigia ao escritório, lá ficando por muitas horas. Outra coisa que minha mãe fazia diariamente, era o cultivo com seu jardim. Só lá, ela gastava três horas. Nosso jardim era belíssimo, e quando o bondinho de Santa Teresa passava, todos paravam de ler jornal, só para olhar as flores, e minha mãe entre elas. Foi ela que começou, no Rio, a tradição das exposições de flores. Todo ano, ela escolhia uma espécie, expondo os exemplares nas vitrines da casa Flora e na Hortulânia. Daí, as exposições de flores foram crescendo de interesse, e outras pessoas também participando. Outra ideia de minha mãe, foram os grandes mercados, que, embora mais tarde implantados, assim mesmo não corresponderam exatamente à sua ideia, tanto que ela escreveu um artigo em $O$ País, reclamando que sua ideia não tinha sido seguida à risca. Mas uma das suas brilhantes ideias, que deu maravilhosos resultados, foi o plantio das hortênsias em Petrópolis. ${ }^{34}$

O que estou querendo demonstrar é o quanto Júlia Lopes de Almeida foi uma brasileira integrada em seu tempo e em sua terra. Preocupada com o país e em como fazê-lo progredir. Em A falência, aborda não só a questão candente na época, a do encilhamento, como o adultério, então somente consentido para homens casados.

Camila, moça muito pobre, aceita o casamento com Francisco Teodoro como forma de escapar da miséria, mas só se apaixona realmente mais tarde, já com quatro filhos. O conhecimento do Dr. Gervásio ocorre por força de uma urgência médica, a doença da filha Ruth, a quem ele atende e salva da morte pelo tifo. A partir daí, o negociante, extremamente grato, introduz o médico na casa da família, que ele passa a frequentar, de início aos poucos, e depois cotidianamente.

\footnotetext{
33 Jornadas no meu país. Rio de Janeiro: Francisco Alves, 1920, p. 117-119.

${ }^{34}$ FLORES, Noemi. Júlia Lopes de Almeida. In: Brasileiras notáveis. Florianópolis: Mulheres; Santa Cruz do Sul: EDUNISC, 2006, p. 191.
}

Camila é uma personagem que vai sendo construída pelo médico, seu futuro amante. Homem estranho, calado, vive para a arte, para o belo que exige ao seu redor. É um homem culto, reservado e um bom observador da alma humana. Quando conhece Camila, é ela ainda uma mulher sem refinamento, natural. E ele, tal Pigmalião, vai transformando-a não só a ela, a sua Galateia, como o que a cerca e seus hábitos: casa, jardins, refeições, modo de viver, de falar, de agir. No início de seu relacionamento, não amara Camila. "Nesse tempo ela não sabia ataviar-se, nem fazer sentir a sua formosura. Tinha os modos de uma boa mãe tranquila, muito banal...” (p. 75).

Aos poucos vão acontecendo as mudanças e nascendo a paixão entre eles, paixão derivada dessa construção...

A evolução não foi rápida, mas refletida e suave, como impelida por sopros delicados. Quando o médico percebeu quanto Camila mudava, e que essa transformação lenta e visível se fazia ao influxo dos seus gostos, da sua convivência e do seu espírito, começou a observá-la com redobrada atenção, cultivando o prazer de a tornar outra, como que uma obra sua.

Camila usava agora as cores claras, que lhe iam bem, e que ele lembrara como mais propícias à sua tez, adquiria expressões novas, inflexões de voz em que nascia uma música de tons coloridos e harmoniosos, fazia outros gestos, mais graves e adequados, pisava de maneira mais ritmada e linda, deixou os perfumes misturados, sem escolha, por uma essência branda; e tudo isso o fazia sem esforço, obedecendo à sugestão. O médico via nela um reflexo perfeito da sua alma, sentia-a voltar-se, subir para ele; e absorvido nesse estudo delicado - apaixonou-se por ela (p. 67).

A escritora, apesar de sua maneira de ver a vida de casada e seu senso de moral burguesa, olha para Camila com compreensão. A personagem trai o marido, mas é igualmente traída não só pelo marido, como pelo próprio amante e, ao final, sofre profundamente com o suicídio de Francisco Teodoro, somente então compreendendo que foi igualmente traída pelo amante que era casado e nunca lho dissera. E o mais grave, separou-se da esposa por ela lhe ter sido infiel!

Depois desse desengano, Camila revê a própria vida, conscientizando-se da realidade e volta-se para a comunidade de mulheres (Nina, Noca, Ruth), traz as gêmeas que foram para a casa da baronesa, esposa do filho mais velho, como forma de ajuda, e planeja alfabetizá-las e educá-las, ela mesma. Fecha-se, assim, o ciclo das personagens centrais do livro que não mais dependem de nenhum homem e "terão de agora em diante de encontrar o sustento pelas próprias mãos". Restam as mulheres forçadas a sobreviver sem estarem preparadas para tanto, um tema dileto de Júlia Lopes de Almeida, que 
acreditava que só o trabalho e a educação poderiam fazer surgir o verdadeiro talento e a capacidade para a luta na vida cotidiana. ${ }^{35}$

Mas esse enredo, que traço brevemente, é apenas a linha principal do livro, que constrói um notável painel da sociedade burguesa do Rio de Janeiro da época, de modo irônico e com crítica bastante mordaz. Os mais ignóbeis motivos das ações sociais são desvendados por essa escritora que, apesar de nossos esforços em republicar-lhe a obra, continua bastante e injustamente esquecida. No final do século XIX, é ela, depois de Machado, o escritor brasileiro mais importante no Brasil.

Analisando-lhe a obra toda, descobre-se que a cada romance, Júlia Lopes de Almeida projetava suas ideias e conceitos: escreveu sobre os preconceitos raciais como temas secundários em alguns romances; escreveu sobre paixões proibidas, como em $A$ viúva Simões, e deixou livros sobre questões ecológicas. Em seu Livro das donas e donzelas, escreveu sobre a educação de toda mulher, e em Livro das noivas, especialmente, as orientou para o casamento. Mas, sobretudo, lutou pela inserção da mulher na sociedade brasileira. Foi uma escritora completa, vivendo em sociedade, observando a vida brasileira e transcrevendo sua fina crítica com arte para seus romances.

\section{Referências}

"Biografia de D. Julia", inédito de Margarida Lopes de Almeida. Documento no acervo da autora, de propriedade do dr. Cláudio Lopes de Almeida.

A Mensageira. Ed. fac-similar de 15 de junho de 1899, v. 2. São Paulo: Imprensa Oficial do Estado, Secretaria de Estado da Cultura, 1987. p. 101

ALBUQUERQUE, José Joaquim de Campos da Costa Medeiros e. Páginas de crítica. Rio de Janeiro: Leite Ribeiro \& Maurillo, 1920. p. 96.

ALMEIDA, Júlia Lopes de. A árvore (coletânea de crônicas e poemas). Rio de Janeiro: Livraria Francisco Alves, 1916.

ALMEIDA, Júlia Lopes de. Jardim florido. Jardinagem. Rio de Janeiro: Leite Ribeiro, 1922.

ALMEIDA, Júlia Lopes de. Jornadas no meu país. Rio de Janeiro: Francisco Alves, 1920, p. 117-119.

ALMEIDA, Júlia Lopes de. Livro das noivas. 2. ed. Rio de Janeiro: Francisco Alves, 1905.

ALMEIDA, Júlia Lopes de. Livro das donas e donzelas. Rio de Janeiro: Francisco Alves, 1906.

ARNONI PRADO, Antonio. Lima Barreto: o crítico e a crise. São Paulo: Martins Fontes, 1989. p. 40.
CANDIDO, Antonio. Prefácio da $2^{\mathrm{a}}$ edição. Formação da literatura brasileira (Momentos decisivos). v. 1. São Paulo: EDUSP; Belo Horizonte: Itatiaia, 1975. p. 18.

DE LUCA, Leonora. Júlia Lopes de Almeida e o feminismo no Brasil da virada do século. Relatório final de pesquisa de Iniciação Científica. IFCH/UNICAMP, 1995.

LUFT, Celso Pedro. Dicionário de Literatura Portuguesa e Brasileira. Porto Alegre: Editora Globo, 1979. p. 11.

MARTINS, Wilson. História da inteligência brasileira. São Paulo: Cultrix; Editora da Universidade de São Paulo, 19771979 (7 volumes). v. 5 (1897-1914). p. 12.

MIGUEL-PEREIRA, Lúcia. Escritos da maturidade. Organização e pesquisa de Luciana Viegas. Rio de Janeiro: Graphia Editorial, 1994. p. 75.

MIGUEL-PEREIRA, Lúcia. História da literatura brasileira - prosa de ficção. De 1870 a 1920. 3. ed. Rio de Janeiro: José Olympio; Brasília: INL, 1973. p. 269-271.

MOREIRA, Nadilza. Disponível em: <http://www.prodema. ufpb.br/revistaartemis/numero1/arquivos/artigos/artigos_finais/ artigo_nadilza.htm>.

MUZART, Zahidé Lupinacci et. al. Escritoras brasileiras do século XIX. Florianópolis: Mulheres; Santa Cruz do Sul: EDUNISC. 3 v.

FLORES, Noemi. Júlia Lopes de Almeida. In: Brasileiras notáveis. Florianópolis: Mulheres; Santa Cruz do Sul: EDUNISC, 2006. p. 191.

SEVCENKO, Nicolau. Introdução. História da vida privada no Brasil. República: da Belle Époque à Era do Rádio. São Paulo: Companhia das Letras, 1998. p. 14-15.

SHARPE, Peggy. Júlia Lopes de Almeida. In: MUZART, Zahidé Lupinacci. Escritoras brasileiras do século XIX. v. 2. Florianópolis: Mulheres; Santa Cruz do Sul: EDUNISC, 2004. p. 188

TELLES, Norma. Apresentação. In: A falência. Florianópolis: Mulheres; Santa Cruz do Sul: EDUNISC, 2003.

TORRESÃO, Guiomar. A Mensageira, n. 29, 15 jun., 1899. p. 100.

VERISSIMO, José. Trecho de História Literária. Correio da Manhã, Rio de Janeiro, 20 abril, 1947. $2^{\mathrm{a}}$ seção, p. 1, apud MIGUEL-PEREIRA, Lúcia. Escritos da maturidade. Organização e pesquisa de Luciana Viegas. Rio de Janeiro: Graphia Editorial, 1994. p. 75.

VERISSIMO, José. Um romance da vida fluminense. In: Estudos de literatura brasileira. Rio de Janeiro: H. Garnier, 1910. p. 141-51.

VERISSIMO, José. Letras e literatos. Rio de Janeiro: José Olympio, 1936. p. 15.

Recebido: 24 de abril 2014 Aprovado: 11 de setembro 2014 Contato: zmuzart@gmail.com 